Buana Sains Vol 19 No 1: 91 - 102, 2019

\title{
REVIEW : \\ PEMANFAATAN TEKNOLOGI GREENHOUSE DAN \\ HIDROPONIK SEBAGAI SOLUSI MENGHADAPI \\ PERUBAHAN IKLIM \\ DALAM BUDIDAYA TANAMAN HORTIKULTURA
}

\author{
Edi Tando
}

Balai Pengkajian Teknologi Pertanian Sulawesi Tenggara

\begin{abstract}
Horticulture plant is essential component of agricultural development. It brings benefits products horticulture meet their food needs, aesthetic and to maintain health and environment. Climate change and the limited resources land causing loss for farmers food crops and horticulture. The purpose of drafting this paper is to inform the utilization of technology greenhouse and hydroponics as solutions to deal with climate change in the cultivation of plants horticulture.

To get the result harvest season which is satisfying in the cultivation of plants horticulture, need to pay attention to environmental factor growing plants. The utilization of greenhouse in the cultivation of plants is one of a manner to give the environment that were more accessible for the condition of optimum position for the growth of plants. The use of hydroponics in cultivation crop can be implemented in greenhouse to keep the growth of plants optimally and protected from outside influences
\end{abstract}

Keywords: Climate change; horticulture; hydroponic; green house; technology.

\section{Pendahuluan}

Jumlah penduduk semakin bertambah menuntut tersedianya bahan pangan yang dapat memenuhi kebutuhan penduduk untuk kelangsungan hidupnya. Salah satu bahan pangan yang menjadi kebutuhan penduduk adalah komoditas hortikultura, karena menjadi salah satu penyedia gizi berupa serat, vitamin, protein dan lain-lainnya yang dibutuhkan oleh tubuh manusia (Sebayang, 2014).

Tanaman hortikultura merupakan komponen penting dalam pembangunan pertanian. Pemasaran produk komoditas hortikultura telah mampu memenuhi kebutuhan pasar dalam negeri maupun luar negeri (ekspor), sehingga mampu menghasilkan devisa untuk negara. Selanjutnya tumbuhnya kesadaran konsumen bahwa produk hortikultura membawa manfaat ganda, yaitu untuk memenuhi kebutuhan pangan, kesehatan dan estetika serta menjaga lingkungan hidup. Badan Litbang Pertanian telah menghasilkan beberapa teknologi dan varietas tanaman hortikultura khususnya pada tanaman sayuran, buah-buahan dan tanaman hias (Balitbangtan, 2015)

Umumnya tanaman hortikultura yang digunakan adalah tanaman semusim yaitu sayur-sayuran seperti cabai, sawi, 
kubis, tomat, dll. Sedangkan untuk tanaman buah yang memiliki manfaat dalam memenuhi gizi keluarga, digunakan semusim dan tahunan. Tanaman hortikultura mempunyai berbagai macam fungsi yaitu sumber pendapatan, sumber pangan tambahan, fungsi estetika/keindahan dan penghasil tanaman rempah/obat (Ginting 2010).

Perubahan iklim saat ini telah membuat para petani tanaman pangan dan hortikultura banyak mengalami kerugian. Keadaan cuaca yang tidak menentu menyebabkan musim tanam dan panen tak menentu. Petani sulit untuk melalukan prediksi cuaca dalam masa tanam. Teknologi greenhouse atau rumah tanaman merupakan sebuah alternatif solusi untuk mengendalikan kondisi iklim mikro pada tanaman (Ridwan, 2011).

Semakin langkanya sumberdaya lahan, terutama akibat perkembangan sektor industri dan jasa, sehingga kegiatan usaha pertanian konvensional semakin tidak kompetitif karena tingginya harga lahan. Teknologi budidaya pertanian sistem hidroponik memberikan alternatif bagi para petani yang memiliki lahan sempit atau yang hanya memiliki pekarangan rumah untuk dapat melaksanakan kegiatan usaha yang dapat dijadikan sebagai sumber penghasilan yang memadai. (Roidah, 2014)

Tujuan dari penulisan ini ialah untuk memberikan informasi pemanfaatan teknologi greenhouse dan hidroponik sebagai solusi menghadapi perubahan iklim dalam budidaya tanaman hortikultura.

\section{Hasil dan Pembahasan}

Tanaman hortikultura dapat memenuhi kebutuhan jasmani sebagai sumber vitamin, mineral dan protein (dari buah dan sayur), serta memenuhi kebutuhan rohani karena dapat memberikan rasa tenteram, ketenangan hidup dan estetika (dari tanaman hias/bunga). Komoditas hortikultura yang diutamakan adalah yang bernilai ekonomi tinggi, mempunyai peluang pasar besar dan mempunyai potensi produksi tinggi serta mempunyai peluang pengembangan teknologi. Komoditas unggulan yang mendapat prioritas adalah : 1) Sayuran : kentang, cabe merah, kubis, bawang merah, tomat dan jamur, 2) Buah-buahan : pisang, mangga, jeruk, nenas dan manggis, 3) Tanaman hias : anggrek, 4) Tanaman obat: jahe dan kunyit (Soleh Solahuddin, 1999). Namun dalam pengelolaannya, hasil komoditas hortikultura memiliki sifat khas yaitu : a). Tidak dapat disimpan lama, b) Perlu tempat yang lapang (voluminous), c) sangat mudah rusak (perishable) dalam pengangkutan, d) melimpah pada suatu musim dan langka pada musim yang lain, e) fluktuasi harganya tajam (Notodimedjo, 1997).

\section{Faktor Lingkungan pada Tanaman Hortikultura}

Pratigna dan Wartoyo (2009) menyatakan bahwa untuk memperoleh hasil produksi/panen yang memuaskan dalam budidaya tanaman hortikultura, maka perlu memperhatikan faktor lingkungan tumbuh tanaman. Hal ini identik dengan faktor luar dan faktor di sekitar tanaman, dimana faktor dalam tanaman mempunyai peranan juga dalam produktivitas tanaman hortikultura. Faktor dalam pada tanaman yang dikendalikan oleh gen (DNA) disebut sebagai faktor keturunan (genetik). Interaksi antara genotype dan lingkungan ( $G \times E$ ) dapat bersifat positif atau negatif. Untuk menentukan interaksi tersebut (positif atau negatif), suatu varietas tanaman hortikultura sebelum disebarkan ke petani hendaknya 
diadakan pengujian terlebih dahulu pada daerah setempat. Pelaku hortikultura hendaknya mengetahui keadaan lingkungan setempat dimana mereka mengusahakan tanaman hortikultura. Dalam hal ini petani harus mengetahui tentang hama/penyakit penting yang dapat menyerang, gulma, kondisi tanah maupun iklim yang dapat membatasi pencapaian produksi maksimum dari tanaman yang diusahakan. Beberapa komponen faktor lingkungan yang penting dalam menentukan pertumbuhan dan produksi tanaman di antaranya adalah : radiasi matahari, suhu, tanah, air dan unsur hara).

\section{A. Radiasi Matahari.}

Radiasi matahari merupakan faktor utama di antara faktor iklim yang lain, tidak hanya sebagai sumber energi primer tetapi karena pengaruhnya terhadap keadaan faktor-faktor yang lain seperti : suhu, kelembaban dan angin. Respon tanaman terhadap radiasi matahari pada dasarnya dapat dibagi menjadi tiga aspek, yaitu : intensitas, kualitas dan fotoperiodisitas (Ketiga aspek ini mempunyai pengaruh yang berbeda satu dengan yang lainnya, demikian juga keadaannya di alam)

\section{Intensitas Cahaya.}

Intensitas cahaya adalah banyaknya energi yang diterima oleh suatu tanaman per satuan luas dan per satuan waktu (kal/cm2/hari). Pengertian intensitas disini sudah termasuk didalamnya lama penyinaran, yaitu lama matahari bersinar dalam satu hari, karena satuan waktunya menggunakan hari.

Besarnya intensitas cahaya yang diterima oleh tanaman tidak sama utuk setiap tempat dan waktu, karena tergantung:

a. Jarak antara matahari dan bumi, misalnya pada pagi dan sore hari intensitasnya lebih rendah dari pada siang hari karena jarak matahari lebih jauh. Juga di daerah sub tropis, intensitasnya lebih rendah dibanding daerah tropis. Demikian pula di puncak gunung intensitasnya $(1,75$ g.kal/cm2/menit) lebih tinggi dari pada di dataran rendah (di atas permukaan laut $=1,50$ g.kal $/ \mathrm{cm} 2 /$ menit).

b. Tergantung pada musim, misalnya pada musim hujan intensitasnya lebih rendah karena radiasi matahari yang jatuh sebagian diserap awan, sedangkan pada musim kemarau pada umumnya sedikit awan sehingga intensitasnya lebih tinggi.

c. Letak geografis, sebagai contoh daerah di lereng gunung sebelah utara/selatan berbeda dengan lereng sebelah timur/barat. Pada daerah tanaman menerima sinar matahari lebih sedikit dari pada sebelah utara/selatan karena lama penyinarannya lebih pendek disebabkan terhalang oleh gunung. Bahkan lereng sebelah barat dan timur itu sendiri juga sering terdapat perbedaan terutama pada musim hujan. Hal ini disebabkan karena musim hujan biasanya banyak sore hari sehingga lebih banyak awan dibanding pagi hari, akibatnya lereng sebelah barat yang baru meneroma sinar matahari sore hari akan mendapatkan radiasi dengan intensitas yang sangat rendah.

Pengaruh intensitas cahaya
terhadap pertumbuhan dan
perkembangan tanaman sejauh mana berhubungan erat dengan proses fotosintesis. Dalam proses ini energi cahaya sangat diperlukan untuk berlangsungnya penyatuan $\mathrm{CO}_{2}$ (karbondioksida) dan $\mathrm{H}_{2} \mathrm{O}$ (air) untuk membentuk karbohidrat. 
2. Kualitas Cahaya

Cahaya matahari yang sampai pada tajuk atau kanopi tanaman tidak semuanya dapat dimanfaatkan, sebagian dari cahaya tersebut diserap, sebagian ditransmisikan, atau bahkan dipantulkan kembali. Kualitas cahaya matahari ditentukan oleh proporsi relatif panjang gelombangnya, selain itu kualitas cahaya tidak selalu konstan namun bervariasi dari musim ke musim, lokasi geografis serta perubahan komposisi udara di atmosfer.

Pengertian cahaya berkaitan dengan radiasi yang terlihat (visible) oleh mata, dan hanya sebagian kecil saja yang diterima dari radiasi total matahari. Radiasi matahari terbagi dua, yaitu yang bergelombang panjang (long wave radiation) dan yang bergelombang pendek (short wave radiation). Batas terakhir dari radiasi gelombang pendek adalah radiasi ultraviolet, sedangkan batas akhir radiasi gelombang panjang adalah sinar inframerah. Radiasi dengan panjang gelombang antara 400 hingga 700 um adalah yang digunakan untuk proses fotosintesis. Ukuran panjang gelombang masing - masing radian seperri pada Gambar 1.
Cahaya matahari yang sampai ke bumi hanya sebagian saja, selebihnya cahaya tersebut tersaring oleh beberapa komponen atmosfer atau dipantulkan kembali ke angkasa luar. Cahaya matahari gelombang pendek tersaring dan diserap oleh lapisan ozon $\left(\mathrm{O}_{3}\right)$ di atmosfer, sedangkan cahaya gelombang panjang tersaring oleh uap air di udara, cahaya gelombang panjang lainnya dipecahkan/dipencarkan dan dipantulkan oleh awan dan lapisan debu di atas permukaan bumi. Pengaruh kualitas cahaya terhadap pertumbuhan dan perkembangan tanaman telah banyak diselidiki, dimana diketahui bahwa spektrum yang nampak (visible) diperlukan untuk pertumbuhan tanaman. Apabila tanaman ditumbuhkan pada cahaya biru saja daunnya akan berkembang secara normal, namun batangnya akan menunjukkan tandatanda terhambat pertumbuhannya. Apabila tanaman ditumbuhkan pada cahaya kuning saja, cabang-cabangnya akan berkembang tinggi dan kurus dengan buku (internode) yang panjang dan daunnya kecil-kecil. Dari penelitian tersebut telah membuktikan bahwa cahaya biru dan merah memegang peranan penting untuk berlangsungnya proses fotosintesis.

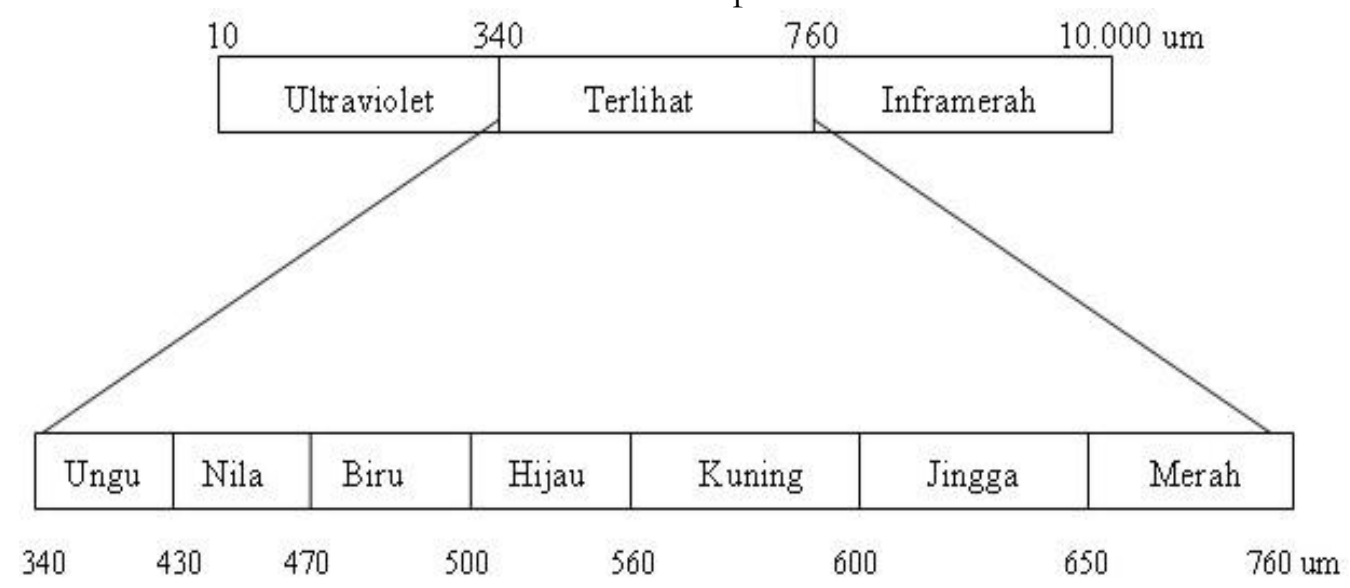

Gambar 1. Panjang gelombang radiasi matahari

3. Fotoperiodisitas 
Fotoperiodisitas atau panjang hari didefinisikan sebagai panjang atau lamanya siang hari dihitung mulai dari matahari terbit sampai terbenam ditambah lamanya keadaan remangremang (selang waktu sebelum matahari terbit atau setelah matahari terbenam pada saat matahari berada pada posisi $6^{0}$ di bawah cakrawala). Panjang hari tidak terpengaruh oleh keadaan awan seperti pada lama penyinaran yang bisa berkurang bila matahari tertutup awan, sedang panjang hari tetap. Panjang hari berubah beraturan sepanjang tahun sesuai dengan deklinasi matahari dan berbeda pada setiap tempat menurut garis lintang. Pada daerah equator panjang hari sekitar 12 jam per harinya, semakin jauh dari equator panjang hari dapat lebih atau kurang sesuai dengan pergerakan matahari. Secara umum dapat dikatakan bahwa semakin lama tanaman mendapatkan pencahayaan matahari, semakin intensif proses fotosintesis, sehingga hasil akan tinggi. Akan tetapi fenomena ini tidak sepenuhnya benar karena beberapa tanaman memerlukan lama penyinaran yang berbeda untuk mendorong fase pembungaan. Fotoperiodisitas tidak hanya berpengaruh terhadap jumlah makanan yang dihasilkan oleh suatu tanaman, tetapi juga menentukan waktu pembungaan pada banyak tanaman. Berdasarkan respon tanaman terhadap panjang hari (fotoperiodisme) maka tanaman dapat digolongkan menjadi tiga kelompok : a) Golongan tanaman hari panjang (long day plants), b) Tanaman hari pendek (short day plants) dan c). Tanaman hari netral (neutral day plants).

\section{B. Suhu.}

Sumber panas di bumi adalah dari matahari yang suhunya pada permukaannya diperkirakan sebesar $6.000^{\circ} \mathrm{C}$, dan energi yang dikeluarkan dari sinar matahari dipancarkan ke seluruh arah dengan kekuatan yang konstan. Jumlah panas yang diterima oleh bumi dan atmosfer hanya sekitar 4 per sepuluh juta dari total energi yang dipancarkan. Sebagian energi sinar matahari berupa gelombang pendek. Sinar matahari yang mengenai atmosfer bumi sebanyak $10 \%$ adalah gelombang sinar ultra violet, $40 \%$ gelombang sinar yang dapat dilihat (visible), sedangkan sisanya $50 \%$ berupa gelombang sinar infra merah.

Energi yang dipancarkan oleh sinar matahari tidak langsung diterima oleh permukaan bumi, tetapi beberapa di antaranya dipantulkan atau dialihkan melalui beberapa media serapan. Pada lapisan atmosfer yang menyerap gelombang sinar ultra violet adalah laipsan ozon dan gas oksigen. Dua jenis lapisan gas tersebut sangat berguna bagi tanaman, hewan dan manusia karena melindungi kehidupan di bumi yang tidak kuat terhadap penyinaran sinar ultra violet.

Pengaruh suhu terhadap pertumbuhan dan perkembangan tanaman dibedakan sebagai berikut : (1) Batas suhu yang membantu pertumbuhan dan perkembangan tanaman, dan (2) Batas suhu yang tidak membantu pertumbuhan dan perkembangan tanaman.

Berdasarkan hal ini tanaman hortikultura dikelompokkan sebagai berikut :

a. Tanaman yang menghendaki batas suhu optimum yang rendah (tanaman musim dingin), yaitu tanaman yang tumbuh baik pada suhu antara : $45^{\circ}$ $60^{\circ} \mathrm{F}$.

b. Tanaman yang menghendaki batas suhu optimum yang tinggi (tanaman musim panas), yaitu tanaman yang tumbuh baik pada suhu antara : $60^{\circ}$ $75^{\circ} \mathrm{F}$. 


\section{Tanah}

Pokok-pokok dari faktor tanah meliputi : 1) Sejumlah air yang tersedia di dalam tanah, 2) Jarak yang ditempuh pergerakan air yang tersedia, 3) Kecepatan pergerakan air yang tersedia 4) Oksigen yang tersedia didalam tanah.

1) Air yang tersedia dalam tanah.

Air tanah terdapat pada pori-pori kapiler dan non kapiler dan selaput pada permukaan butir-butir tanah. Keadaan air tanah dibedakan menjadi :

a) Keadaan kapasitas menahan air maksimum, seluruh pori baik pori mikro maupun makro terisi penuh air.

b) Keadaan kapasitas lapang, bila air telah mencapai keadaan maksimum selama beberapa waktu terjadi pergerakan air ke bawah sampai akhirnya gerakan terhenti, keadaan demikian disebut kapasitas lapang ( Field capasity). Disini pori makro sebagian diisi udara, sedang pori mikro penuh dengan air.

c) Keadaan titik layu, yaitu keadaan air tanah sudah sangat berkurang, dimana ruang pori makro dan mikro tidak berisi air.

d) Keadaan air higroskopis, yaitu air sudah habis sama sekali, kecuali pada permukaan partikel-partikel tanah sebagai air adsorbsi yang amat sulit dilepaskan.

Pada prinsipnya ada dua tipe air yang terdapat dalam tanah, yakni :

air tersedia, dan (2) air yang tidak tersedia. Air tersedia kadang disebut air kapiler dan dipegang oleh daya kapileritet, sedang kapasitas lapang sama dengan jumlah air tak tersedia dan air tersedia. Air yang tidak tersedia disebut juga dengan air higroskopis dan terikat secara mantap oleh koloid tanah.

\section{Unsur Hara}

Unsur hara atau nutrisi merupakan faktor penting bagi pertumbuhan tanaman yang dapat diibaratkan sebagai zat makanan bagi tanaman. Sesuai dengan jumlah yang dibutuhkan tanaman, unsur hara dapat dikelompokkan ke dalam dua bagian, yaitu unsur hara makro dan unsur hara mikro. Unsur hara makro adalah unsur hara yang dibutuhkan tanaman dalam jumlah banyak, seperti : nitrogen $(\mathrm{N})$, fosfor $(\mathrm{P})$, kalium $(\mathrm{K})$, belerang $(\mathrm{S})$, kalsium (Ca) dan magnesium (Mg). Unsur hara makro sering dibagi menjadi dua bagian, yakni unsur hara primer $(\mathrm{N}$, $\mathrm{P}$ dan $\mathrm{K}$ ) dan unsur hara sekunder $(\mathrm{S}, \mathrm{Ca}$ dan $\mathrm{Mg}$ ). Selain unsur hara tersebut, tanaman juga mambutuhkan unsur lain yang juga dalam jumlah besar, yaitu : karbon $(\mathrm{C}$, hidrogen $(\mathrm{H})$ dan oksigen $(\mathrm{O})$. Namun unsur-unsur ini ( $\mathrm{C}, \mathrm{H}$ dan $\mathrm{O}$ ) jarang dibicarakan, bukan karena peranannya kecil akan tetapi karena ketersediaannya dialam yang berlimpah serta peranannya dalam proses metabolisme tidak berdiri sendiri. Kekurangan unsur ini juga tidak dapat dilihat secara terpisah. Unsur $\mathrm{C}$ diserap tanaman dalam bentuk $\mathrm{CO}_{2}$ dalam proses fotosintetis, unsur $\mathrm{H}$ diserap dalam bentuk $\mathrm{H}_{2} \mathrm{O}$ dan unsur $\mathrm{O}$ diserap dalam bentuk $\mathrm{O}_{2}$ pada proses respirasi. Sedangkan yang tergolong unsur hara mikro (dibutuhkan dalam jumlah kecil), antara lain besi $(\mathrm{Fe})$, borron (B), mangan $(\mathrm{Mn})$, seng $(\mathrm{Zn})$, tembaga $(\mathrm{Cu})$ dan molibdenum (Mo).

Jumlah energi yang dibutuhkan bagi penyerapan aktif unsur hara tanaman diperoleh dari respirasi karbohidrat yang terbentuk sebagai hasil dari fotosintesis tanaman. Oleh karenanya sejumlah faktor yang mengurangi laju fotosintesis, akan mengurangi suplai energi di dalam tanaman dalam waktu lama dan akibatnya mengurangi laju penyerapan unsur hara.

Setiap unsur hara memiliki peran spesifik dalam tanaman, namun demikian 
ada beberapa unsur yang berperan ganda. Karena setiap unsur memainkan peran khusus, maka suatu keadaan defisit atau berlebihan umumnya akan mengakibatkan gejala khas. Bila sejenis unsur memiliki lebih dari satu peran khusus, maka akan timbul berbagai macam efek defisiensi bergantung pada proses dalam tanaman yang dipengaruhi.

Agar tanaman tumbuh sempurna, maka sebaiknya semua unsur esensial harus tersedia dalam jumlah cukup. Jika lebih dari sejenis hara yang kurang dalam suatu tanaman, maka akan kecil respon tanaman tersebut bila yang diberikan hanya satu unsur hara diantaran0ya. Beberapa faktor lain, seperti : hama, penyakit, gulma dan faktor pembatas yang lain juga akan menurunkan respon tanaman terhadap pemupukan. Diagram berikut ini menunjukkan peran yang dimainkan sejumlah unsur hara dalam proses fotosintesis dan sintesis karbohidrat.

\section{Peranan Teknologi Green House dan Teknologi Hidroponik untuk Tanaman}

\section{a. Peranan Green House untuk tanaman}

Greenhouse atau dikenal dengan rumah kaca, dimanfaatkan dalam budidaya tanaman hortikultura seperti sayuran \& tanaman hias. Green house merupakan sebuah bangun kontruksi dengan atap tembus cahaya yang berfungsi memanipulasi kondisi lingkungan agar tanaman di dalamnya dapat berkembang optimal. Manipulasi lingkungan ini dilakukan dalam dua hal, yaitu menghindari kondisi lingkungan yang tidak dikehendaki dan memunculkan kondisi lingkungan yang dikehendaki (Ruadi, 2013).

Green house untuk daerah tropis sangat memungkinkan dan mempunyai banyak keuntungan dalam produksi dan budidaya tanaman. Produksi dapat dilakukan sepanjangtahun, di mana produksi dalam lahan yang terbuka tidak memungkinkan karena adanya hujan yang sering dan angin yang kencang. Struktur greenhouse di daerah tropis sering menggunakan sisinya untuk melindungi dan mengontrol suhu dengan menggunakan ventilasi alamiah maupun terkontrol dengan dilapisi jala (screens) yang mampu mengurangi serangan serangga dan hama (Sukamto, 2013).

Penggunaan greenhouse dalam budidaya tanaman merupakan salah satu cara untuk memberikan lingkungan yang lebih mendekati kondisi optimum bagi pertumbuhan tanaman. Green house dikembangkan pertama kali dan umum digunakan di kawasan yang beriklim subtropika. Penggunaan greenhouse terutama ditujukan untuk melindungi tanaman dari suhu udara yang terlalu rendah pada musim dingin (Suhardiyanto, 2009)

Dengan greenhouse beberapa kondisi lingkungan berikut dapat dihindari, antara lain : a) Perubahan suhu dan kelembaban yang fluktuatif, b) Akibat buruk yang di timbulkkan dari radiasi sinar matahari jenis sinar ultra violet dan sinar infra red, c) Kekurangan air pada musim kemarau dan kelebihan air pada musim penghujan, d) Hama dan binatang pengganggu serta penyakit tanaman seperti jamur dan bakteri, e) Tiupan angin kencang yang dapat merobohkan tanaman dan merusak daun, f) Tiupan angin dan serangga yang dapat menggagalkan proses penyerbukan bunga, g) Akibat buruk dari polusi udara. Kondisi lingkungan yang dapat di ciptakan dengan adanya greenhouse, antara lain: 1) Kondisi cuaca yang mendukung pertumbuhan tanaman, 2) Suhu, kelembaban dan intensitas cahaya 
matahari dapat di atur sesuai kebutuhan, 3) Penyiraman tanaman dapat diatur berkala, 4) Kebersihan lingkungan dapat dijaga dengan baik sehingga terhindar dari penyakit tanaman, 5) Kenyamanan terhadapa aktivias produksi dan pengendalian mutu, 6) Udara yang bersih dari polutan dan 7) Insklusi (terlindung) terhadap gangguan binatang/hama dan serangga penggangu (Mulyono, 2014)

\section{b. Peranan Teknologi Hidroponik untuk Tanaman}

Roidah (2014) menyatakan bahwa teknologi hidroponik merupakan sistem budidaya tanaman tanpa menggunakan tanah tetapi menggunakan air yang berisi larutan nutrient. Budidaya tanaman secara hidroponik dilakukan di dalam rumah kaca (greenhouse) untuk menjaga supaya pertumbuhan tanaman secara optimal dan benar - benar terlindung dari pengaruh unsur luar seperti hujan, hama penyakit, iklim, dll. Keunggulan dari beberapa budidaya dengan menggunakan sistem hidroponik antara lain : 1) Kepadatan tanaman per satuan luas dapat dapat dilipat gandakan sehingga menghemat penggunaan lahan. (2) Mutu produk seperti bentuk, ukuran, rasa, warna, kebersihan dapat dijamin karena kebutuhan nutrient tanaman dipasok secara terkendali di dalam rumah kaca.(3) Tidak tergantung musim/waktu anam dan panen, sehingga dapat diatur sesuai dengan kebutuhan pasar. Jenis hidroponik dapat dibedakan dari media yang digunakan untuk berdiri tegaknya tanaman. Media tersebut biasanya bebas dari unsur hara (steril), sementara itu pasokan unsur hara yang dibutuhkan tanaman dialirkan ke dalam media tersebut melalui pipa atau disiramkan secara manual. Media tanam tersebut dapat berupa kerikil, pasir, gabus, arang, zeolite atau tanpa media agregat (hanya air). Yang paling penting dalam menggunakan media tanam tersebut harus bersih dari hama sehingga tidak menumbuhkan jamur atau penyakit lainnya. Sementara keuntungan teknologi hidroponik, yaitu : 1) Keberhasilan tanaman untuk tumbuh dan berproduksi lebih terjamin, 2) Perawatan lebih praktis dan gangguan hama lebih terkontrol, 3) Pemakaian pupuk lebih hemat (efisien), 4) Tanaman yang mati lebih mudah diganti dengan tanaman yang baru, 5) Tidak membutuhkan banyak tenaga kasar karena metode kerja lebih hemat dan memiliki standarisasi, 6) Tanaman dapat tumbuh lebih pesat dan dengan keadaan yang tidak kotor dan rusak, 7) Hasil produksi lebih kontinue dan lebih tinggi apabila dibandingkan dengan penanaman di tanah, 8) Harga jual hidroponik lebih tinggi dari produk non hidroponik, 9) Beberapa jenis tanaman dapat dibudidayakan di luar musim, 10) Tidak ada resiko kebanjiran,erosi, kekeringan, atau ketergantungan dengan kondisi alam, 11) Tanaman hidroponik dapat dilakukan pada lahan atau ruang yang terbatas, misalnya di atap, dapur atau garasi.

\section{Aplikasi Teknologi Greenhouse dan Hidroponik dalam Budidaya Tanaman Hortikultura}

Pengelolaan media dan lokasi tumbuh tanaman secara optimal merupakan syarat utama untuk tanaman pangan. Teknologi greenhouse merupakan suatu alternatif dalam mengontrol kondisi lingkungan tumbuh tanaman hortikultura yang tidak sesuai syarat tumbuh tanaman, akibat serangan hama, angin, suhu lingkungan serta kelengasan tanah hingga penyinaran (Telaumbanua, 2014). 


\section{Aplikasi Teknologi Greenhouse untuk sayuran daun}

Salah satu bentuk aplikasi atau pemanfaatan teknologi greenhouse dalam budidaya tanaman hortikultura, yaitu pada budidaya sayuran. Teknik budidaya sayuran di dalam greenhouse merupakan salah satu alternatif untuk meningkatkan produksi pada kondisi lahan yang semakin sempit sebagai akibat dari konversi lahan pertanian menjadi kawasan industri dan pemukiman. Keuntungan yang dapat diperoleh dari teknik budidaya tanaman sayuran di dalam greenhouse antara lain adalah pertumbuhan tanaman terkontrol, produksi tidak bergantung musim, serta harga jual komoditi lebih tinggi dibandingkan dengan harga jual komoditi yang dibudidayakan secara tradisional di lahan terbuka (Sebayang, 2014).

Beberapa kelebihan pemanfaatan teknologi green house dalam budidaya tanaman, yaitu : a) Hasil produksi yang meningkat ; karena berjalannya pengawasan (control) tanaman yang dibudidayakan dalam greenhouse, misalnya saat tanaman kekurangan unsur hara, dapat segera dilakukan penambahan unsur hara sesuai kebutuhan tanaman, sehingga mampu menjaga keseimbangan unsur hara dan mampu meningkatkan produksi. b. Kualitas produksi yang jauh lebih baik ; karena pemberian nutrisi maupun perawatan tanaman secara berkala dan kontinyu akan menghindarkan tanaman dari sinar ultraviolet, kelebihan suhu, atau polutan. Sehingga akan memberikan dampak positif pada peningkatan kualitas produksi tanaman. c. Mengurangi penggunaan pestisida ; karena terpasangnya insec-screen pada dinding greenhouse sehingga mampu menghalangi masuknya beberapa hama penting tanaman, seperti kutu loncat ataupun kutu daun, serta d. Sebagai sarana agrowisata ; karena pada beberapa jenis greenhouse dapat dimanfaatkan sebagai sebagai lahan bisnis agrowisata melalui budidaya berbagai tanaman langka, seperti tanaman anggrek, buah dan beberapa tanaman lainnya (Hidrafarm, 2016)

Tanaman sawi ialah suatu jenis sayuran daun yang tumbuh di dataran rendah maupun tinggi, serta banyak disukai karena memiliki kandungan pro vitamin A dan asam askorbat yang tinggi (Setiawati et al., 2007). Sementara menurut Telaumbanua (2014) bahwa salah satu jenis tanaman hortikultura yang umum dibudidayakan ialah tanaman sawi (Brassica rapa var. parachinensis L.) di lahan terbuka memiliki banyak kendala sehingga dapat mempengaruhi pertumbuhan dan produktivitas tanaman selanjutnya. Budidaya tanaman di rumah tanaman (greenhouse) merupakan alternatif yang baik untuk mengontrol kendala tersebut.

Hasil penelitian Telaumbanua (2016) menunjukkan bahwa dalam identifikasi pola pertumbuhan tanaman sawi yang dibudidayakan dengan sistem hidroponik pada greenhouse menunjukkan bahwa suhu pada pertumbuhan luas daun sawi yang terbaik ialah suhu $35{ }^{\circ} \mathrm{C}$ dengan luas daun 565,41 $\mathrm{cm}^{2}$, cahaya pada pertumbuhan luas daun sawi yang terbaik ialah 17000 lux dengan luas daun 697,42 cm2, nutrisi pada pertumbuhan luas daun sawi yang terbaik ialah $5 \mathrm{mS} / \mathrm{cm}$ dengan luas daun 639,27 $\mathrm{cm} 2$, sementara kombinasi untuk pertumbuhan terbaik tanaman sawi yaitu pada kombinasi suhu $35{ }^{\circ} \mathrm{C}$, nutrisi 5 $\mathrm{mS} / \mathrm{cm}$ dengan cahaya 17000 lux, dengan luas permukaan daun 1068,83 $\mathrm{cm}^{2}$, sedangkan pertumbuhan terendah nampak pada suhu $38{ }^{\circ} \mathrm{C}$, nutrisi $8 \mathrm{mS}$ dengan luas maksimal $201,71 \mathrm{~cm}^{2}$. 


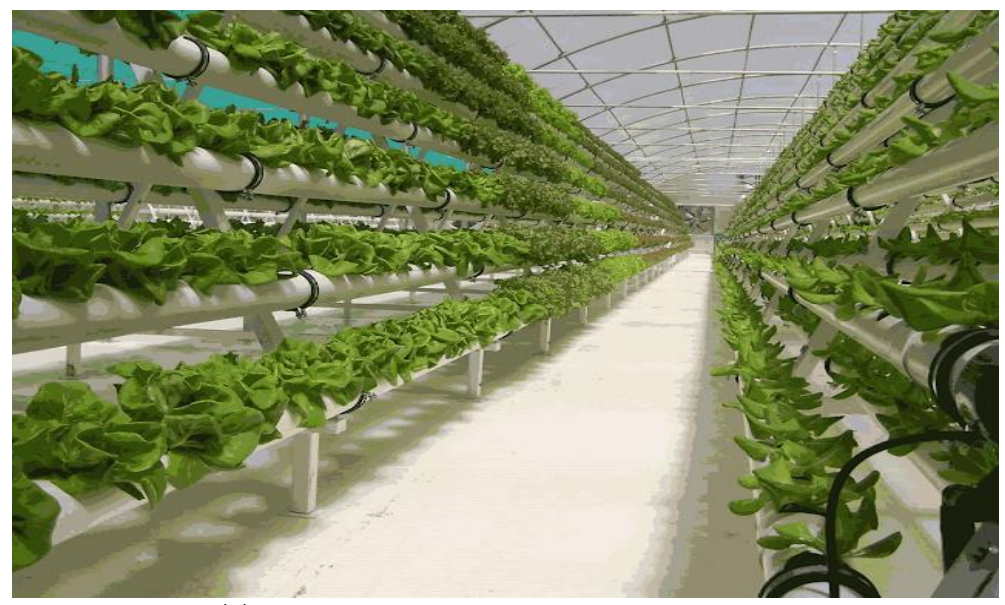

sumber : http://hidrafarm.blogspot.com)

Gambar 2. Teknologi green house untuk sayuran daun

\section{Aplikasi Teknologi Hidroponik untuk buah tomat}

Saat ini buah tomat merupakan salah satu komoditas hortikultura yang bernilai ekonomi tinggi, namun masih memerlukan penanganan serius untuk peningkatan hasil dan kualitas buah. Kemampuan tomat dalam menghasilkan buah sangat tergantung pada interaksi pertumbuhan tanaman dan kondisi lingkungan tumbuh.

Aplikasi atau pemanfaatan teknologi hidroponik merupakan upaya dalam menanggulangi permasalahan dalam teknik budidaya buah tomat. Pemanfaatan sistem hidroponik mampu mengatur kondisi lingkungan tumbuh tanaman, seperti suhu, intensitas cahata, kelembaban, curah hujan serta memperkecil serangan hama penyakit tanaman. (Sundstrom (1982) dalam Wijayani (2005).

Berdasarkan hasil penelitian Wijayani (2005) menunjukkan bahwa buah tomat varietas Bonanza dan Kaliurang 206 yang dibudidayakan menggunakan teknologi hidroponik memiliki keunggulan melalui bobot buah, jumlah buah, kekerasan buah maupun kadar vitamin C lebih tinggi daripada buah tomat varietas Intan.

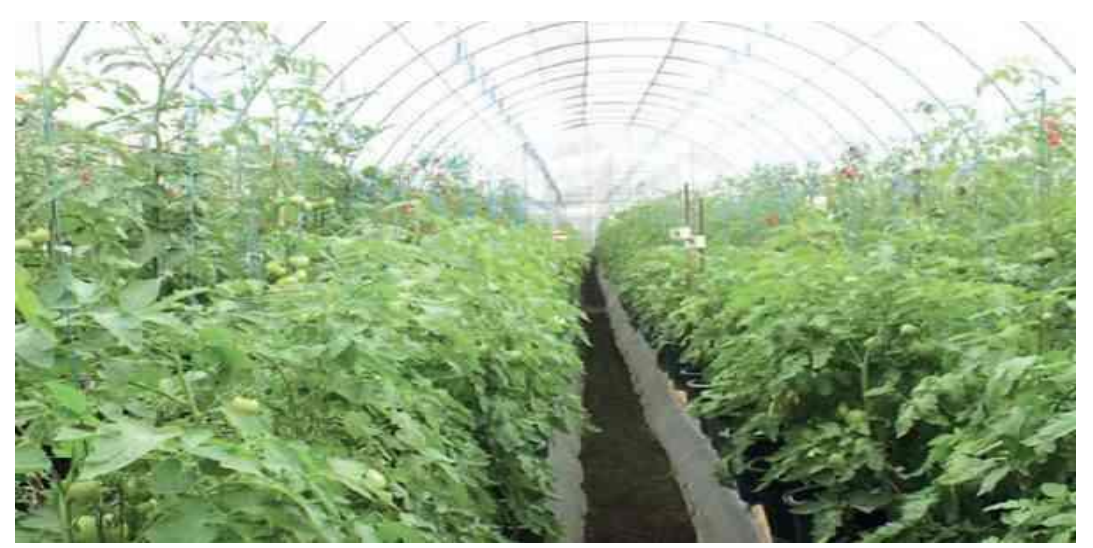

(Sumber : https://www.pertanianku.com

Gambar 2. Teknologi hidroponik untuk buah tomat 


\section{Kesimpulan}

1. Untuk memperoleh hasil panen memuaskan dalam budidaya tanaman hortikultura, perlu memperhatikan faktor lingkungan tumbuh tanaman.

2. Teknologi Greenhouse dan Hidroponik dapat dimanfaatkan dalam budidaya tanaman hortikultura seperti sayuran daun, buah, tanaman hias yang memiliki nilai ekonomis yang tinggi.

3. Pemanfaatan greenhouse dalam budidaya tanaman merupakan salah satu cara untuk memberikan lingkungan yang lebih mendekati kondisi optimum bagi pertumbuhan tanaman.

4. Pemanfaatan hidroponik dalam budidaya tanaman dapat dilaksanakan dalam greenhouse untuk menjaga pertumbuhan tanaman secara optimal dan terlindung dari pengaruh luar.

\section{Daftar Pustaka}

Badan Penelitian dan Pengembangan Pertanian. 2015. Inovasi Hortikultura Pengungkit Peningkatan Pendapatan Rakyat. Badan Penelitian dan Pengembangan Pertanian, Kementerian Pertanian. IAAR Press. 294 PP.

Ginting, M 2010. Eksplorasi Pemanfaatan Pekarangan secara Konseptual Sebagai Konsep "Program Gerakan Dinas Pertanian Kota Pematang siantar". Diakses pada 27 Desember 2018 http://musgin.wordpress.com/201 0/03/27/pemanfaatanpekarangan/ diambil 27 September 2010.

Hidrafarm, 2016. Kelebihan dan Kekurangan Sayuran Hidroponik di dalam Greenhouse. Diakses pada 27 Desember 2018 http://hidrafarm.blogspot.com.

Mulyono L. 2014. Fungsi , Manfaat dan Kegunaan Greenhouse. Diakses pada 27 Desember 2018 http://www.uvplastik99.com. 2 pp.

Notodimedjo, Soewarno. 1997. Strategi Pengembangan Hortikultura Khususnya Buah-buahan dalam menyongsong Era Pasar Bebas. Pidato Pengukuhan Guru Besar dalam Ilmu Hortikultura, Fak.Pertanian Unibraw, Malang. 74 pp.

Pertanianku. 2016. Inilah Keuntungan Bertanam Tomat di Dalam Pot. Diakses pada 27 Desember 2018 https://www.pertanianku.com.

Pratignja S. dan Wartoyo. 2006. Buku Ajar Dasar Hortikultura. Fakultas Pertanian Universitas Sebelas Maret, Surakarta. 70 pp.

Ridwan U. 2011. Greenhouse Solusi untuk Menghadapi Perubahan Iklim dalam Budidaya Pertanian. Diakses pada 27 Desember 2018 https://inspirasitabloid.wordpress. com.

Roidah S.I. 2014. Pemanfaatan Lahan Dengan Menggunakan Sistem Hidroponik. Jurnal Universitas Tulungagung. (1) (2) : 43 - 50

Ruadi MP. 2013. Laporan Outsourhing Di Balai Penelitian Tanaman Hias (Balithi) Menganalisis Jenis Green House. Diakses pada 27 Desember 2018 http://anaktptphagriculture.blogspot.com.

Sebayang L. 2014. Bercocok Tanam Paprika. Balai Pengkajian Teknologi Pertanian Sumatera Utara. 35 pp. 
Setiawati W, Murtiningsih R, Sopha G.A., dan Handayati T. 2007 : Petunjuk Teknis Budidaya Tanaman Sayuran. Balai Penelitian Tanaman Sayuran Pusat Penelitian dan Pengembangan Hortikultura Badan Penelitian dan Pengembangan Pertanian.

Soleh Solahuddin, 1999. Penajaman Strategi dan Kebijakan Pembangunan Pertanian Dalam Rangka Memperkokoh Sistem Pertanian Nasional. Gerakan Terpadu Peduli Pertanian, Undip Semarang. 21 pp.

Suhardiyanto H. 2009. Teknologi Rumah Tanaman untuk Iklim Tropika Basah, Pemodelan dan Pengedalian Lingkungan. IPB Press.

Sukamto A. 2014. Manfaat dan Tujuan Greenhouse. Diakses pada 27 Desember 2018 https://www.academia.edu.

Telaumbanua, M. Bambang, P. dan Lilik, S. 2014. Rancangbangun Aktuator Pengendali Iklim Mikro di dalam Greenhouse untuk Pertumbuhan Tanaman Sawi (Brassica rapa var.parachinensis L.). Jurnal Agritech. 34 (2) : 213-222.

Wijayani A dan Widodo, W. 2005. Usaha Meningkatkan Kualitas Beberapa Varietas Tomat dengan Sistem Budidaya Hidroponik. Jurnal Ilmu Pertanian 12 (1) : $77-83$. 